\title{
BACK-ALLEY
}

BANKING 
This page intentionally left blank 


\section{BACK-ALLEY BANKING}

Private Entrepreneurs in China

Kellee S. Tsai

Cornell University Press

ITHACA AND LONDON 


\section{Copyright $(12002$ by Cornell University}

All rights reserved. Except for brief quotations in a review, this book, or parts thereof, must not be reproduced in any form without permission in writing from the publisher. For information, address Cornell University Press, Sage House, 512 East State Street, Ithaca, New York 14850.

First published 2002 by Cornell University Press

First printing Cornell Paperbacks 2004

Printed in the United States of America

\section{Library of Congress Cataloging-in-Publication Data}

Tsai, Kellee S.

Back-alley banking : private entrepreneurs in China / Kellee S. Tsai.

p. $\mathrm{cm}$.

Includes bibliographical references and index.

ISBN 0-8014-3928-0 (cloth : alk. paper)

ISBN 0-8014-8917-2 (pbk.: alk. paper)

1. Finance-China. 2. Financial institutions-China. 3. Informal sector (Economics)-China. 4. Banks and banking-China. I. Title. HG187.C6 T726 2002

$330-\mathrm{dc} 21$

Cornell University Press strives to use environmentally responsible suppliers and materials to the fullest extent possible in the publishing of its books. Such materials include vegetable-based, low-VOC inks and acid-free papers that are recycled, totally chlorine-free, or partly composed of nonwood fibers. For further information, visit our website at www.cornellpress.cornell.edu.

$\begin{array}{lllllllllll}\text { Cloth printing } & 10 & 9 & 8 & 7 & 6 & 5 & 4 & 3 & 2 & 1 \\ \text { Paperback printing } & 10 & 9 & 8 & 7 & 6 & 5 & 4 & 3 & 2 & 1\end{array}$


For my mother 
The Brownian motion of social life-the emergence of destabilizing opportunity out of stabilizing methods-provides the occasion for influences that may shape long-term context change. These influences, working in concert or in opposition, account for a remarkable possibility. Contexts may change in quality as well as content. They vary in the force with which they imprison the people who move within them. 